\title{
Tardigrada of the Caribbean island of Dominica (West Indies)
}

\author{
Juliana G. HINTON, ${ }^{*}$ Harry A. MEYER, Brittany N. SOILEAU, Alison P. DUPUIS \\ Department of Biology and Health Sciences, McNeese State University, 4205 Ryan St., Lake Charles, 70609 LA, USA \\ *Corresponding author: jhinton@meneese.edu
}

\begin{abstract}
In June 2009 we surveyed the terrestrial Tardigrada of Dominica, the most northerly of the Windward islands of the Lesser Antilles in the Caribbean sea. Out of 112 moss, lichen, liverwort and leaf litter samples, 35 had tardigrades, representing 10 genera and 25 species or species groups. This survey increases the number of species reported from Dominica from 3 to 25, more than the total recorded from any other West Indian island. Twelve species found in Dominica are cosmopolitan or belong to cosmopolitan species groups. Eight species are new to the fauna of the West Indies, one is new to the fauna of the Americas, and at least one is endemic to Dominica.
\end{abstract}

Key words: Caribbean fauna, tardigrades, West Indies, water bears, biogeography.

\section{INTRODUCTION}

The first investigations of water bears (Phylum Tardigrada) in the West Indies were made in the mid-20 th century, when du Bois-Reymond Marcus (1960) found four species in the Netherlands Antilles. Since then there have been few studies of terrestrial and freshwater tardigrades from islands of the Caribbean sea. These studies have been limited to the Greater Antilles islands of Puerto Rico (Fox and Garcia-Moll, 1962; Beasley, 1981; Jaime Jerez, 2003), the Dominican Republic (Schuster and Toftner, 1982; Kaczmarek et al., 2007), Cuba (Kaczmarek and Michalczyk, 2002) and Grand Cayman (Meyer, 2011), and in the Lesser Antilles, Curaçao (du Bois-Reymond Marcus, 1960), Los Testigos (du Bois-Reymond Marcus, 1960), Saint Lucia (Iharos, 1982), Barbados (Meyer and Hinton, 2012), and Dominica (Meyer, 2012), and a new Dominican species described by Meyer (2012).

The West Indian island of Dominica, officially the Commonwealth of Dominica is approximately $750 \mathrm{~km}^{2}$, and is the most northerly of the Windward islands. Volcanic in origin, Dominica has a very rugged topography with elevations of $1447 \mathrm{~m}$. Unlike many Caribbean islands, it retains large expanses of virgin tropical wet rainforest (James, 2004). Yearly rainfall in the mountains ranges from 5000 to $9000 \mathrm{~mm}$.

This paper provides the first survey of the Tardigrada from Dominica.

\section{METHODS}

\section{Sampling}

Sampling was conducted from 18 to 23 June 2009. In total, we collected 112 moss, lichen, liverwort and leaf litter samples. All samples were stored in paper envelopes until laboratory processing, when they were soaked overnight and examined with a stereoscopic microscope (Nikon SMZ-U Zoom 1:10; Nikon, Tokyo, Japan). Specimens were mounted on slides in polyvinyl lactophenol and examined using phase contrast microscopy (Nikon Eclipse 50i).

Tardigrades were identified using keys and descriptions in Nelson and McInnes (2002), Ramazzotti and Maucci (1983), Pilato and Binda (2010) and by reference to the primary literature. Tardigrade taxonomic nomenclature follows Guidetti and Bertolani (2005), Degma and Guidetti (2007) and Degma et al. (2012). Comments on tardigrade biogeography are based on McInnes (1994). Species are considered cosmopolitan if they meet the criterion of Pilato and Binda (2001), namely that they have been found in five or more biogeographical realms.

\section{Localities}

i. $1520.77^{\circ} \mathrm{N}, 6122.16^{\circ} \mathrm{W}, 348 \mathrm{~m}$ asl: Saint Paul parish, Archbold Tropical Research and Education Center, tropical rainforest, 18, 21, 23 June 2009 collected 49 samples- 8 moss, 4 moss plus lichen, 4 lichen, 2 liverwort and 19 leaf litter.

ii. $1519.59^{\circ} \mathrm{N}, 6120.52^{\circ} \mathrm{W}, 483 \mathrm{~m}$ asl: Saint Paul parish, Morne Trois Pitons National Park, Middleham falls, tropical rainforest, 19 June 2009 collected 13 samples8 moss, 4 liverwort and 1 leaf litter.

iii. $1520.43^{\circ} \mathrm{N}, 6118.35^{\circ} \mathrm{W}, 779 \mathrm{~m}$ asl: Saint George parish, Freshwater lake, 19 June 2009 collected 7 samples- 4 moss and 3 liverwort.

iv. $1535.02^{\circ} \mathrm{N}, 6128.24^{\circ} \mathrm{W}, 51 \mathrm{~m}$ asl: Saint John parish, Cabrits National Park, dry tropical forest, 19 June 2009 collected 6 samples-4 moss and 2 leaf litter .

v. $1523.44^{\circ} \mathrm{N}, 6118.39^{\circ} \mathrm{W}, 415 \mathrm{~m}$ asl: Saint David 
parish, Emerald pool, tropical rainforest, 19 June 2009 collected 22 samples-13 moss, 1 liverwort and 3 leaf litter.

vi. $1531.43^{\circ} \mathrm{N} 6125.17^{\circ} \mathrm{W}, 538 \mathrm{~m}$ asl: Saint Peter parish, Syndicate trail, Northern Forest Preserve, tropical rainforest, 20 June 2009 collected 14 samples- 9 moss, 1 lichen, 1 liverwort and 3 leaf litter.

vii. $1531.43^{\circ} \mathrm{N} 6125.17^{\circ} \mathrm{W}, 538 \mathrm{~m}$ asl: Saint Peter parish, Morne Diablotin Trail, Northern Forest Preserve, 19 June 2009 collected 1 sample-moss.

\section{RESULTS}

Only 35 of 112 samples of cryptogams and leaf litter contained tardigrades and their eggs. In these samples, 265 specimens and 12 eggs (representing 10 genera and 23 species or species groups) were found.

List of species:

i. Echiniscus barbarae Kaczmarek and Michalczyk, 2002

LOCALITIES: 1

MATERIAL: 4 specimens from 1 moss sample

REMARKS: The first record outside the locus typicus (Cuba island) (Kaczmarek and Michalczyk, 2002).

ii. Echiniscus cavagnaroi Schuster and Grigarick, 1966 LOCALITIES: 1

MATERIAL: 1 specimen from 1 lichen sample

REMARKS: Species known from few localities in North, South and Central America (McInnes, 1994). Previously reported also from the West Indies (Dominican Republic) (Schuster and Toftner, 1982).

iii. Pseudechiniscus brevimontanus Kendall-Fite and Nelson, 1996

LOCALITIES: 1

MATERIAL: 1 specimen from 1 moss sample

REMARKS: The first record outside the locus typicus (North America) (Kendall-Fite and Nelson, 1996).

iv. Pseudechiniscus cf. suillus

LOCALITIES: 1 and 2

MATERIAL: 59 specimens from 5 samples of lichen, liverwort and moss.

REMARKS: It is a cosmopolitan species group with many very similar species, known from many localities through the world (McInnes, 1994). Previously reported from the West Indies in Dominica, Dominican Republic and Puerto Rico (Beasley, 1981; Schuster and Toftner, 1982; Meyer, 2012).

v. Milnesium sp. 1

LOCALITIES: 1 and 2

MATERIAL: 3 specimens and one exuvium (with four eggs) from one moss sample.

REMARKS: This species has a smooth cuticle, six peribuccal lamellae, a cylindrical buccal tube and [33]-[3-3] claw configuration.

vi. Milnesium sp. 2
LOCALITIES: 1 and 4

MATERIAL: 4 specimens from lichen and moss samples.

REMARKS: This species has a smooth cuticle, six peribuccal lamellae, a cylindrical buccal tube and [22]-[2-2] claw configuration.

vii. Milnesium cf. tardigradum

LOCALITIES: 1 and 4

MATERIAL: 9 specimens and one exuvium (with four eggs) from nine moss, lichen and leaf litter samples. REMARKS: These specimens meet the criteria of Michalczyk et al. (2012a, b) for Milnesium cf. tardigradum, a cosmopolitan species group (McInnes, 1994). The full identification is not possible because the specimens were not oriented nor mounted adequately for morphometric analysis.

viii. Diphascon (Diphascon) pingue (Marcus, 1936)

LOCALITIES: 1

MATERIAL: 2 specimens from one moss sample.

REMARKS: This species belongs to cosmopolitan pingue group of very similar species which can be determined only by morphometric characters (Fontoura and Pilato, 2007). Our specimens perfectly corresponded to the redescription in Pilato and Binda (1997/1998). It is the first report from the West Indies.

ix. Hypsibius convergens (Urbanowicz, 1925)

LOCALITIES: 1

MATERIAL: 3 specimens from one banana leaf litter sample.

REMARKS: Considered as cosmopolitan in the past, it is most likely a group of very similar species found throughout the world (McInnes, 1994), see also Kaczmarek and Michalczyk (2009). Previously, it was found in West Indies on St. Lucia (Iharos, 1982).

X. Astatumen trinacriae (Arcidiacono, 1962)

LOCALITIES: 6

MATERIAL: 2 specimens from one lichen and moss sample.

REMARKS: Holarctic species. It is the first report of this species from the West Indies.

xi. Doryphoribius flavus (Iharos, 1966)

LOCALITIES: 6

MATERIAL: 26 specimens plus four eggs in exuvium from two moss samples.

REMARKS: Cosmopolitan species, previously found in Dominican Republic.

xii. Doryphoribius quadrituberculatus Kaczmarek and Michalczyk, 2004

LOCALITIES: 1

MATERIAL: 4 specimens from two moss samples. REMARKS: The first record outside the locus typicus (Costa Rica) (Kaczmarek and Michalczyk, 2004).

xiii. Doryphoribius taiwanus X. Li and H. Li, 2008 LOCALITIES: 1 
MATERIAL: 2 specimens from one moss sample.

REMARKS: The first record outside the locus typicus (Taiwan) (Li and Li, 2008).

xiv. Macrobiotus echinogenitus Richters, 1904

LOCALITIES: 1, 6

MATERIAL: 27 specimens from six moss, lichen and leaf litter samples.

REMARKS: Cosmopolitan species, but it probably represents a group of species. Previously it was found in West Indies on Curaçao (du Bois-Reymond Marcus, 1960).

xv. Macrobiotus cf. harmsworthi \#1

LOCALITIES: 1, 6

MATERIAL: 25 specimens from three samples of moss and lichen on trees and one leaf litter sample.

Remarks: Cuticles smooth, colourless/white. The correct identification of this species is possible only based on the adults and eggs (Kaczmarek et al., 2011). The Macrobiotus harmsworthi group is cosmopolitan and had been previously reported in West Indies from Barbados, Puerto Rico and Los Testigos (du Bois-Reymond Marcus, 1960; Beasley, 1981; Meyer and Hinton, 2012).

xvi. Macrobiotus cf. harmsworthi \#2

LOCALITIES: 1,4

MATERIAL: 9 specimens from two lichen and banana leaf litter samples.

REMARKS: Cuticle smooth, brown. No eggs found.

xvii. Macrobiotus cf. hufelandi C.A.S. Schultze, 1833

LOCALITIES: 1

MATERIAL: 7 specimens from two moss and lichen samples.

REMARKS: The correct identification of this species is possible only based on the adults and eggs (Bertolani and Rebecchi, 1993). The Macrobiotus hufelandi group is cosmoplitan and had been previously reported in West Indies from Dominican Republic (Schuster and Toftner, 1982).

xviii. Macrobiotus occidentalis Murray, 1910

LOCALITIES: 4 and 5

MATERIAL: 7 specimens from two moss and lichen samples.

REMARKS: It is the first record of this species from the West Indies.

xix. Macrobiotus cf. polyopus

LOCALITIES: 1

MATERIAL: 9 specimens from three moss and lichen samples.

REMARKS: The correct identification of this species is possible only based on the adults and eggs (Pilato, 2006; Pilato and Kaczmarek, 2007). The species from Macrobiotus polyopus group have a disjunct tropical distribution (Pilato, 2006). This is the first record of this species from the West Indies. xx. Minibiotus fallax Pilato, Claxton and Binda, 1989

LOCALITIES: 1 and 6

MATERIAL: 2 specimens from two moss and lichen samples.

REMARKS: It is the first record of this species from the West Indies.

xxi. Minibiotus furcatus (Ehrenberg, 1859)

LOCALITIES: 1

MATERIAL: 4 specimens from two moss and lichen samples.

REMARKS: It is the first record of this species from the West Indies.

xxii. Minibiotus cf. intermedius

LOCALITIES: 1 and 6

MATERIAL: 24 specimens from eight moss and lichen samples.

REMARKS: Cosmopolitan species group, requiring eggs for identification (Claxton, 1998). Previously reported from Grand Cayman (Meyer, 2011) and Puerto Rico (Beasley, 1981).

xxiii. Minibiotus julianae Meyer, 2012

LOCALITIES: 1

MATERIAL: 6 specimens and 2 eggs from one moss sample.

REMARKS: This species has not been recorded outside the locus typicus (Dominica) (Meyer, 2012).

xxiv. Paramacrobiotus cf. areolatus

LOCALITIES: 1 and 4

MATERIAL: Site: 5 specimens found in two moss and leaf litter samples.

REMARKS: The correct identification of this species is possible only based on the adults and eggs. The Paramacrobiotus genus is cosmopolitan (with many new species described in last few years, also in Central America (Michalczyk and Kaczmarek, 2006; Michalczyk et al., 2006; Pilato et al., 2006; Bartels et al., 2009) and had been previously reported from Dominican Republic (Schuster and Toftner, 1982) and Grand Cayman (Meyer, 2011).

xxv. Paramacrobiotus richtersi (Murray, 1910)

Localities: 1, 2, 6, and 7

MATERIAL: 20 specimens and 1 egg from 6 moss and leaf litter samples.

REMARKS: Cosmopolitan species group (see above), previously reported from Barbados (Meyer and Hinton, 2012), Grand Cayman (Meyer, 2011), Puerto Rico (Beasley, 1981), Saint Lucia (du Bois-Reymond Marcus, 1960) and Dominican Republic (Schuster and Toftner, 1982; Jaime Jerez, 2003).

\section{DISCUSSION}

Among the islands of the West Indies, only Grand Cayman, Hispaniola (Dominican Republic portion) and Puerto Rico have hitherto been systematically surveyed 
for terrestrial tardigrades. Our survey increases the number of tardigrade species known to occur on Dominica from three to 25 , a number more than that of any other West Indian island.

Twelve of 25 species found in Dominica are cosmopolitan or belong to cosmopolitan species groups. Eight species are new to the fauna of the West Indies, one is new to the fauna of the Americas, and at least one is endemic to Dominica. It is worth noting that only $31 \%$ of samples collected had tardigrades; large numbers of samples from multiple sites need to be taken to get a true picture of tardigrade species richness. No survey, including this one, has collected freshwater tardigrades; when such habitats are included in West Indian sampling, the number of recorded species will doubtless increase.

\section{ACKNOWLEDGMENTS}

We wish to thank Mr. Arlington James, Director of the Forestry, Wildlife and ParkDivision, Commonwealth of Dominica, for his help in obtaining collecting and export permits, and Harry L. Meyer and the staff of the Archbold Tropical Research and Education Center for logistical support.

\section{REFERENCES}

Bartels P, Pilato G, Lisi O, Nelson DR, 2009. Macrobiotus (Eutardigrada, Macrobiotidae) from the Great Smoky Mountains National Park, Tennessee/North Carolina, USA (North America): two new species and six new records. Zootaxa 2022:45-57.

Beasley CW, 1981. Some Tardigrada from Puerto Rico. Tex. J. Sci. 33:9-12.

Bertolani R, Rebecchi L, 1993. A revision of the Macrobiotus hufelandi group (Tardigrada, Macrobiotidae), with some observations on the taxonomic characters of eutardigrades. Zool. Scripta 22:127-152.

Claxton SK, 1998. A revision of the genus Minibiotus (Tardigrada: Macrobiotidae) with descriptions of eleven new species from Australia. Records Austr. Mus. 50:125160.

Degma P, Bertolani R, Guidetti R, 2012. Actual checklist of Tardigrada species (2009-2012, Ver. 21:30-06-2012). Available from: http:/www.tardigrada.modena.unimo.it/miscellanea

Degma P, Guidetti R, 2007. Notes to the current checklist of Tardigrada. Zootaxa 1579:41-53.

du Bois-Reymond Marcus E, 1960. Tardigrada from Curaçao, Bonaire and Los Testigos. Studies on the Fauna of Curaçao and other Caribbean Islands 10:52-57.

Fontoura P, Pilato G, 2007. Diphascon (Diphascon) faialense sp. nov. a new species of tardigrada (Eutardigrada, Hypsibiidae) from Azores and a key to the species of the $D$. pingue group. Zootaxa 1589:47-55.

Fox I, Garcia-Moll I, 1962. Echiniscus molluscorum, new tardigrade from the faeces of the land snail, Bulimulus exilis (Gmelin) in Puerto Rico (Tardigrada: Scutechiniscidae). J. Parasitol. 48:177-181.

Guidetti R, Bertolani R, 2005. Tardigrade taxonomy: an updated checklist of the taxa and a list of characters for their identification. Zootaxa 845:1-46.

Iharos G, 1982. Tardigradologische Notizen. I. Misc. Zool. Hungarica 1:8-90.

James A, 2004. Flora and fauna of Cabrits National Park, Dominica. Forestry, Wildlife and Parks Division, Roseau, Dominica: $59 \mathrm{pp}$.

Jaimes Jerez JH, 2003. [Composición de tardígrados en el musgo Calymperes palisotii Schwaegrichen sobre seis forofitos (árboles) en la Universidad de Puerto Rico, Recinto de Mayagüez]. [Degree Thesis in Spanish]. Universidad de Puerto Rico ed., Mayagüez, Puerto Rico, USA: 99 pp.

Kaczmarek Ł, Goldyn B, Prokop ZM, Michalczyk Ł, 2011. New records of Tardigrada from Bulgaria with the description of Macrobiotus binieki sp. nov. (Eutardigrada: Macrobiotidae) and a key to the species of the harmsworthi group. Zootaxa. 2781:29-39.

Kaczmarek Ł, Michałczyk Ł, 2002. Echiniscus barbarae, a new species of tardigrade from Cuba Island (Tardigrada: Heterotardigrada, Echiniscidae, ‘arctomys group'). Zootaxa 53:1-4.

Kaczmarek Ł, Michałczyk Ł, 2004. First record of the genus Doryphoribius Pilato, 1969 from Costa Rica (Central America) and description of a new species Doryphoribius quadrituberculatus (Tardigrada: Hypsibiidae). Genus 15:447-453.

Kaczmarek Ł, Michalczyk Ł, 2009. Redescription of Hypsibius microps Thulin, 1928 and H. pallidus Thulin, 1911 (Eutardigrada: Hypsibiidae) based on the type material from the Thulin collection. Zootaxa 2275:60-68.

Kaczmarek Ł, Michałczyk Ł, Degma P, 2007. Description of a new tardigrade, Macrobiotus barbarae (Eutardigrada: Macrobiotidae) from the Dominican Republic. Ann. Zool. (Warszawa) 57:363-369.

Kendall-Fite K, Nelson DR, 1996. Two new species of tardigrades from Short Mountain, Tennessee. U.S.A. Zool. J. Linn. Soc. 116: 205-214.

Li XC, Li H, 2008. Tardigrades from Taiwan, with the description of a new species of Doryphoribius (Tardigrada, Hypsibiidae). Zool. Sci. 25:554-559.

McInnes SJ, 1994. Zoogeographic distribution of terrestrial /freshwater tardigrades from current literature. J. Nat. Hist. 28: 257-352.

Meyer HA, 2011. Tardigrada of Grand Cayman, West Indies, with descriptions of two new species of eutardigrades, Doryphoribius tessellatus (Hypsibiidae) and Macrobiotus caymanensis (Macrobiotidae). Zootaxa 2812:28-40.

Meyer HA, 2012. A new water bear, Minibiotus julianae, from the Caribbean Island of Dominica (Tardigrada: Eutardigrada: Parachela: Macrobiotidae). Proc. Biol. Soc. Washington, 125:54-60.

Meyer HA, Hinton JG, 2012. Terrestrial Tardigrada of the island of Barbados in the West Indies, with the description of Milnesium barbadosense n. sp. (Eutardigrada: Apochela: Milnesiidae). Caribb. J. Sci. 46:194-202.

Michalczyk $€$ and Kaczmarek, Ł, 2006. A new species Macrobiotus magdalenae (Tardigrada: Eutardigrada: Macrobiotidae, richtersi group) from Costa Rican rain forest (Central America). New Zeal. J. Zool. 33:189-196.

Michalczyk Ł, Kaczmarek, Ł, Weglarska B, 2006. Macrobiotus 
sklodowskae sp. nov. (Tardigrada: Eutardigrada: Macrobiotidae, richtersi group) from Cyprus. Zootaxa 1371:45-46.

Michalczyk Ł, Welnicz W, Frohme M, Kaczmarek Ł, 2012a. Redescriptions of three Milnesium Doyère, 1840 taxa (Tardigrada: Eutardigrada: Milnesiidae), including the nominal species for the genus. Zootaxa 3154:1-20.

Michalczyk Ł, Wełnicz W, Frohme M, Kaczmarek Ł, 2012b. Corrigenda of Zootaxa, 3154:1-20. Redescriptions of three Milnesium Doyère, 1840 taxa (Tardigrada: Eutardigrada: Milnesiidae), including the nominal species for the genus. Zootaxa 3393:66-68.

Nelson D, McInnes SJ, 2002. Tardigrada, p. 177-215. In: S.D. Rundle, A. Robertson, J.M. Schmid-Araya (eds.), Freshwater meiofauna: biology and ecology. Backhuys Publ.

Pilato G, 2006. Remarks on the Macrobiotus polyopus group, with description of two new species (Eutardigrada, Macrobiotidae). Zootaxa 1298:37-47.

Pilato G, Binda MG, 1997/1998. A comparison of Diphascon (D.) alpinum Murray, 1906, D. (D.) chilenense Plate, 1889 and $D$. (D.) pingue Marcus, 1936 (Tardigrada), and description of a new species. Zool. Anz. 236:181-185.
Pilato G, Binda MG, 2001. Biogeography and limno-terrestrial tardigrades: are they truly incompatible binomials? Zool. Anz. 240:511-516.

Pilato G, Binda MG, 2010. Definition of families, subfamilies, genera and subgenera of the Eutardigrada, and keys to their identification. Zootaxa 2404:1-54.

Pilato G, Binda M, Lisi O, 2006. Eutardigrada from New Zealand, with descriptions of two new species. New Zeal. J. Zool. 33:49-63.

Pilato G, Kaczmarek Ł, 2007. Macrobiotus alvaroi, a new species of eutardigrade (Tardigrada, Macrobiotidae) of the polyopus group from Costa Rica (Central America). Zootaxa 1479:1-7.

Ramazzotti G, Maucci W, 1983. [Il Phylum Tardigrada. Terza edizione riveduta e aggiornata]. [Article in Italian]. Mem. Ist. Ital. Idrobiol. 41:1-1012.

Schuster RO, Toftner EC, 1982. Dominican Republic Tardigrada, p. 231-235. In: D.R. Nelson (ed.), Proc. Third Int. Symp. on Tardigrades, August 3-6, 1980, Johnson City, Tennessee, USA. 